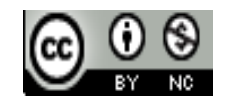

Journal of Education, Teaching, and Learning is licensed under

a Creative Commons Attribution-Non Commercial 4.0 International License.

\title{
FEEDBACK EFFECTIVENESS ATTRIBUTIONAL MODIFICATION SCHUNK MODEL FOR IMPROVEMENT OF ACADEMIC SELF-EFFICACY PRIMARY SCHOOL STUDENTS IN MATH LESSON
}

\author{
Asrori \\ University Tanjungpura, Kalimantan Barat, Indonesia \\ E-mail: asroriuntan@yahoo.com
}

\begin{abstract}
This experimental study examines the effect of Schunk Model's attributional feedback to improve academic selfefficacy of elementary school underachievers and low achievers in mathematics. The hypothesis that student who receives an attributional feedback, either oral or written, both get higher scores on self-efficacy and mathematics achievement than control group was Examined. The elementary students' grade III and IV Whose mathematics Reviews their achievements were below average grade was Involved as a research subject. With the random procedure, the subjects were assigned to one of three groups: (1) oral attributional feedback, (2) written attributional feedback, (3) reinforcement feedback and (4) no treatment. Profile analysis indicates that oral feedback and reinforcement attributional more effective to increase of mathematics self-efficacy and students' achievement than written. Analysis of variance with Least Significant Difference indicates that students who receive either oral or written feedback attributional got higher scores on mathematics selfefficacy and achievement than the control group. Furthermore, factorial design analysis indicates that attributional feedback, either oral or written, was more effective than low achievers to underachievers.
\end{abstract}

Keywords: attributional feedback, self-efficacy, underachievers, low achievers

\section{INTRODUCTION}

The phenomenon is commonly found in school since elementary that in general, the students feel mathematics as a difficult subject, annoying, boring, uninteresting, or even frightening. Consequently, mathematics achievement for most students become not encouraging or lower. If the UN benchmarked student achievement, it is generally the value of UN students on math lesson too low. A further result, not a few students who looked like did not have the self-confidence (self-confidence), indicating high anxiety, lack of motivation which is nice, and do not have efficacy for themselves (selfefficacy) when facing a repeat or a test on lesson mathematics (Asrori, 2008). It has been many efforts have been made to improve the academic self-efficacy and student achievement was less successful in math. However, a systematic intervention based on the concepts and recent findings presumably still relatively rare in research reports are set in our schools. In fact, recent developments, in fact, there are several potential research findings to support the realization of systematic interventions. The findings of this research, in general, can be seen on the research theme motivational intervention (Elliot and Dweck, 2006; Dweck, 2008).
The literature review showed that one of the cutting-edge intervention that a lot of attention is "attributional intervention (attributional intervention)" (Wittrock, 2006). Interventions by Berk (2009) is applied it is proven to generate progress towards the expected (Forsteling, 2006), particularly in the areas of academic achievement (Weiner, 2002) and more specifically in the increased efficacy of self-academic and student achievement were less successful (Berk, 2009; Gredler, 2002; Dweck, 2006, Shunck, 2002; Shunck et al., 2007).

Attributional interventions were found in several studies during this conceptual basis that rests on attributional analysis (Weiner, 2002; Forsteling, 2006). This attributional analysis states that if the student after obtaining low learning outcomes will be desperate or his motivation will be maintained depends on the assumption (attribution) the students about the cause of the low learning results. Students will be desperate if a low hooking the study results with its ability (attribution capability); otherwise the motivation will be maintained if the low learning outcomes attributable to a lack of effort (Weiner, 2002). Thus attributional analysis was supported by many research findings (Juvonnen, 2008; Weiner, 2000; 2002; 2003). This analysis underlying attributional program (Berk, 
2009) found that in its application for variation, one of which is developed by Shunck (2002).

The purpose of this study was to test the effectiveness of attributional feedback Shunck Model (2002) with certain modifications and expansion to increase academic selfefficacy and learning achievement Student Achievement and Student Achievement-Low-Less in mathematics in elementary school. Modifications made in this study are as follows:

First, the type of attributional feedback provided to the subject of research (primary students). If the Model Schunk (2002) separates the attributional feedback on the results of the past (past achievement) and results (future achievement), then in research feedback given to two results at once. Furthermore, if the model is Shunk only use verbal feedback while it was still in the form of recommendation written feedback only (Gredler, 2002), then in this study apply oral and written feedback.

Second, the background (setting) extended treatment. If the Model Shunck (2002) to apply its intervention on the background of a laboratory so it is unclear whether the same efficacy was also observed in an actual classroom setting, in this study the use of the treatment in the actual teachinglearning process in the classroom.

Third, if the Model Schunk intervention attributional given to students who are not successful (Dweck, 2006) without sorting through these students in terms of the capacity of intelligence, namely underachievers and low achievers, so in this study to sharpen the effectiveness of feedback attributional by sorting the two groups the.

With some modifications, as development in this study, it is becoming increasingly visible importance or primacy of the research plan is because the results of this study will be able to offer an intervention attributional more comprehensive and original in order to improve the efficacy of self-academic and student achievement elementary school that had been having not been developed on the background of school in Indonesia. Thus, it will contribute to the development of science, education discipline, and provide guidance to the innovation in the practice of elementary students.

While the self-efficacy variables were included in the study developed the theory of "Self-Efficacy" proposed by Albert Bandura (2007; 2006). The academic self-efficacy, especially in mathematics for elementary school students are the focus of development in this study were drawn from the concept of "Mathematics Self-efficacy," developed by Betz and Hackett (2003).

Self-efficacy (self-efficacy) is a person's belief that he is capable of displaying behaviours required to achieve the desired goals (Bandura, 2007; 2006). Self-efficacy contains two dimensions: (1) efficacy expectancy that is a person's belief that he is capable of displaying certain behaviors that are required to achieve a particular purpose; and (2) the outcome expectancy that one's belief that the behavior shown it can deliver to the achievement of the desired goals (Bandura, 2006; Sanna, 2002). Self-efficacy on a person has an important influence on the patterns of thinking, effective, and behavior (Ryckman, et al., 2002).
Self-efficacy was included in this study as: "self-efficacy Affect choice, initiation, effort, persistence, and hence the performance level of accomplishment" (Bandura, 2006: 194). It also means that self-efficacy may influence confidence, perseverance, and hard work of elementary school students in learning mathematics. Moreover, "... efficacy expectations are a major determinant of people's choice of activities, how much effort they will expend, and how long they will sustain the effort in dealing with the stressful situation" (Bandura, 2006: 194; Sanna, 2002).

The above statement has been proven in many of the findings of previous studies, such as self-efficacy influence on academic performance in math (Betz \& Hackett, 2003); consideration of career and career decision-making capacity (Post-Kammer \& Smith, 2005); academic business, academic perseverance and academic performance (Bores-Rangel et al., 2000; Church et al., 2002; Multon \& Brown, 2003). The findings of this study reinforce the importance of self-efficacy were included in this study to be developed through attributional oral and written feedback.

An important research question to be raised is: "Is the elementary students who obtained oral and written feedback attributional will increase academic self-efficacy and interpretation of study in mathematics? Which of the spoken and written feedback was more effective to increase academic self-efficacy and interpretation of elementary student learning in mathematics? Which among the group of underachievers (student-achievement-low) and low achievers (studentachievement-less) that further increased the efficacy of selfacademic and interpretation of study in mathematics if given feedback verbally and in writing?

"Based on the research questions, then the hypothesis tested in this study is: "students who earn attributional oral and written feedback will show self-efficacy and mathematics achievement higher than students who did not receive treatment. Attributional oral and written feedback showed no significant difference in effectiveness. Attributional oral and written feedback will be effectively imposed on the group of underachievers than low achievers.

"The study involved students of class III and IV SD by taking the mathematics courses for elementary school-age children around the classroom is a vulnerable time for the development of motivation to learn mathematics; as confirmed by Tankersley (2003): "Fear of math is learned somewhere around the 4th grade". In addition, reconstruction of attribution at this age is more effective than the previous age (Berk, 2009) because in previous years are still having difficulty to effective the cognition in an effort attribution.

\section{METHOD}

In this section presented important methodological aspects used in this study are: the study design; the subject of research, experimental procedures, research instruments, and data analysis techniques. 


\section{A. Study Design}

To test the effect of independent variables on vari $\neg$ abel bound, especially testing the effectiveness of a treatment to target behaviour, the most suitable research is experimental peneli-tian (Tuckman, 2008; Goldman, 2008; Kirk, 2002; Cozby, 2005; Heppner, 2002). Therefore, this peneli $\neg$ tian which aims to test keefek $\neg$ tivan Schunk Model attributional feedback to improve students' academic self-efficacy in the elementary math lesson, conducted by using the experimental method. The experimental method used here is a quasiexperimental or quasi-experimental design with "pretestposttest-Control Group Design". With this design, in this study there were three experimental groups and one control group: (1) the experimental group feedback attributional oral, (2) the experimental group feedback attributional writing, (3) the experimental group feedback attributional reinforcement (reinforcement), and (4) as the control group shown in Table 1.

TABLE I

EXPERIMENTAL DESIGN

\begin{tabular}{cccc}
\hline Group & Pretest & Treatment & Posttest \\
\hline Experiment 1 (Feedback attributional \\
$\begin{array}{c}\text { Oral) } \\
\text { Experiment 2 (Feedback attributional }\end{array}$ & $\mathrm{T} 1$ & $\mathrm{Xa}$ & $\mathrm{T} 2$ \\
$\begin{array}{c}\text { Posts) } \\
\begin{array}{c}\text { Experiment 3 (Feedback attributional } \\
\text { Confirmation) } \\
\quad \text { control }\end{array}\end{array}$ & $\mathrm{T} 1$ & $\mathrm{Xb}$ & $\mathrm{T} 2$ \\
(without treatment) & $\mathrm{T} 1$ & - & $\mathrm{T} 2$ \\
\hline
\end{tabular}

\section{B. Research Subjects}

The study included 100 students of class III and IV of SD Muhammadiyah learn math achievement is below the average class. To identify underachievers and low achievers performed with the following procedure. First, to 100 students study subjects plus 20 third-grade students and 20 students of class $\mathrm{V}$ that academic achievement is equal to or higher than the average class given IQ tests by using the tool Wishler Intelligence Scale for Children-Revised (WISC-R). Second, set the average value of the WISC-R each class, from a score of WISC-R 20 students whose academic achievement is equal to or higher than the average class coupled with 20 students study subjects that academic achievement is below average class. In this way, the average value of IQ test results using the WISC-R can represent student academic achievement below, equal to, and above the average class. Third, from 100 students in the subject of the study was classified as a StudentAchievement-Low (underachievers) if the value of the WISC$\mathrm{R}$ test results is equal to or above the average value of the WISC-R were obtained by the students in his class. The research subjects were classified as Student-AchievementLess (low achievers) is the remainder of the subject of research that goes into the classification StudentAchievement-Low (underachievers).

The subject of research, amounting to 100 students, randomly by lottery technique is divided evenly into three experimental groups and one control group. Thus, each group had 25 students.

\section{Experiments Procedure}

Steps experiments in this study using a procedure developed by Mohammad Hatip (1996). Experiments carried out by providing the treatment of research subjects who were in the experimental group, the experimental group feedback either orally, in writing, as well as reinforcement. The treatment is done through two meetings. At the first meeting, feedback attributional focused on results in the future (future achievement attribution), for example, by telling the students (for feedback orally) or write on the answer sheet students (for feedback writing) the words: "You can run a job this if you want to try harder "and the like when the students do math problems in class. At the second meeting, feedback attributional focused on the results of the past (past achievement attribution), for example, by telling the students (for feedback orally) or write on the answer sheet students (for feedback writing) the words: "You have been trying in earnest "and the like by the time students finish their homework and also when students work on math problems in class. The time interval between the first meeting with the second meeting on Sunday.

\section{Research Instruments}

There are three instruments used in this study, that intelligence test WISC-R, inventory of self-efficacy and mathematics achievement test.

1) WISC-R Intelligence Test. This test includes two sub battery tests: verbal and action. The oral test consists of six subs, namely information, similarities, arithmetic, vocabulary, comprehension, and a sequence of numbers. The test also measures consists of six sub, which completes the picture, puzzle, cube design, assemble objects, coding, and garden astray. WISC-R intelligence test used in the study using an instrument adapted by the Foundation for Educational Guidance Center Bandung.

2) Self-Efficacy Inventory. This instrument adapted from the Mathematics Self-Efficacy Inventory developed by Betz and Hackett (1993) which has been tested beforehand. This inventory has 50 items covering two aspects of the efficacy and outcome expectancy 30 items 30 items that have been tested reliability. Cronbach Alpha test showed a high level of reliability, the efficacy, and outcome expectancy .845 .870 . This means qualified to be used as a data collection tool in this study.

3) Learning Outcomes Matematika.Tes test consists of 30 questions tests for each class that has been tested in advance to determine the level of difficulty and reliability. This test questions difficulty level ranges from 0.29 up to 0.70. Alpha Test Cronbach show the reliability coefficient 0,692 for the tests for students 0.721 for Class III and Class IV.

\section{E. Data Analysis}

To determine the profile of academic self-efficacy and student achievement in mathematics were analyzed by finding the percentage of the actual score of the ideal maximum score based on the normal curve. Data pretest and post $\neg$ test of four groups (experimental and control) analyses with variance 
analysis followed by Least Significant Differences Test to see multi comparison significance between groups. As for testing the effectiveness of each comparison feedback on student groups-low-achievers (underachievers) and student-lessachievers (low achievers) performed factorial analysis (Minium, 1998; Kerlinger, 1993). Prog $\neg$ ram Menganali-sisnya using SPSS for MS Windows.

\section{RESULT AND DISCUSSION}

Profile analysis conducted to determine the profile of academic self-efficacy in mathematics obtained the results as shown in Table 2.

TABLE II

Profit ACADEMIC SELF-EFFicACy STUDENTS Before AND AFTER GeTting FEEDBACK ATTRIBUTIONAL

\begin{tabular}{|c|c|c|c|c|c|c|}
\hline \multirow{2}{*}{\multicolumn{2}{|c|}{ Group }} & \multirow[b]{2}{*}{$\mathbf{X}_{\text {ideal }}$} & \multicolumn{2}{|c|}{ pretest } & \multicolumn{2}{|c|}{ posttest } \\
\hline & & & $\overline{\mathbf{X}_{\text {Actual }}}$ & Rate & $\overline{\mathbf{X}_{\text {Actual }}}$ & level \\
\hline A. & Feedback Oral & 12000 & 5040 & $42 \%(\mathrm{~S})$ & 8760 & $73 \%(\mathrm{~T})$ \\
\hline B. & Feedback Posts & 12000 & 4800 & $40 \%(\mathrm{~S})$ & 5760 & $48 \%(\mathrm{~S})$ \\
\hline C. & Feedback & 12000 & 5280 & $44 \%$ (S) & 8400 & $70 \%(\mathrm{~T})$ \\
\hline D. & $\begin{array}{l}\text { Strengthening of } \\
\text { Controls }\end{array}$ & 12000 & 4560 & $38 \%(\mathrm{R})$ & 5520 & $46 \%(\mathrm{~S})$ \\
\hline
\end{tabular}

Description: $(T)=$ High $;(S)=$ Average

Table 2 shows that the efficacy of self-students before getting treatment all of them are in the category of "moderate", either the experimental group or the control group, apparently, after receiving treatment feedback attributional either orally, in writing, as well as strengthening, it showed an increase varied. The group of students who receive treatment and strengthening oral attributional feedback showed significant improvement because it can achieve "high". While students who receive treatment attributional feedback posts and are not getting the treatment did not show an increase because that would still be in the category of "medium".

The profile analyzes the results of student achievement in the elementary mathematics lesson as listed in Table 3.

TABLE III

Profit MATHEMATICS LEARNING ACHIEVEMENT BEFORE AND AFTER GETTING FEEDBACK ATTRIBUTIONAL

\begin{tabular}{lccc}
\hline \multicolumn{1}{c}{ Group } & C Cases & Mean pretest & Meanposttest \\
\hline Feedback A.Oral & 25 & 55.036 & 67.047 \\
B.Feedback Posts & 25 & 53.375 & 55.021 \\
C. feedback reinforcement & 25 & 51.623 & 64.032 \\
D. Controls & 25 & 50.142 & 52.034 \\
$\quad$ entire Group & 100 & 52.544 & 59.533 \\
\hline
\end{tabular}

Table 3 was also demonstrated that oral attributional feedback and reinforcement is more effective influence on improving student achievement than the feedback given in writing or no feedback at all. This is evident from the increase in pretest scores obtained by students in each treatment group to score posttest.

Analysis of variance to determine the significance of the differences between the four groups, the treatment group attributional feedback (oral, written, and reinforcement) and a control group (no treatment is given) to increase students academic self-efficacy is as indicated in Table 4. In the table that shows that there are significant differences between the four groups. It appears from the production of $\mathrm{F}=3.702$ and significant at $\mathrm{p}<0.05$.

TABLE IV

RESULTS OF ANALYSIS OF VARIANCE FOR ACADEMIC SELF-EFFICACY

\begin{tabular}{lccccc}
\hline \multicolumn{1}{c}{ Source } & DB & $\begin{array}{c}\text { number } \\
\text { square }\end{array}$ & $\begin{array}{c}\text { Squares } \\
\text { Mean }\end{array}$ & $\begin{array}{c}\text { F } \\
\text { Ratio }\end{array}$ & F Prob \\
\hline Inter-group & 3 & 1187.532 & 387.871 & 3.702 & 0.016 \\
In Group & 96 & 8682.309 & 112.309 & & \\
Total & 99 & 9764.867 & & & \\
\hline
\end{tabular}

From the analysis of variance was then followed with the Least Significant Differences Test to determine the ratio between groups simultaneously (multicomparison). The results of the analysis as shown in Table 5.

TABLE V

TEST RESUlts MULTIKOMPARASI THE LEAST SIGNIFICANT DiFFERENCES ATTRIBUTIONAL FEEDBACK TO THE STUDENT ACADEMIC SELF-EFFICACY

\begin{tabular}{|c|c|c|c|c|c|}
\hline Mean & Group & (1) & (2) & (3) & (4) \\
\hline 36.105 & Oral Feedback & (1) & & & $*$ \\
\hline 26.437 & Feedback Writing & (2) & & $*$ & \\
\hline 35.557 & feedback & (3) & & & $*$ \\
\hline 26.021 & $\begin{array}{l}\text { Reinforcement } \\
\text { control }\end{array}$ & (4) & & & \\
\hline
\end{tabular}

Table 5 shows that there were significant differences in the groups (1) oral attributional feedback control; (2) strengthening the attributional feedback control; and (3) writing with reinforcement feedback so that it can be understood also that the group of students who received verbal feedback and reinforcement attributional significantly higher efficacy than that-he was not given treatment (control).

Analysis of variance to determine the significance of the differences between the four groups, the treatment group attributional feedback (oral, written, and reinforcement) and a control group (no treatment is given) to increase student achievement in mathematics lesson is as shown in Table 6. In the table below shows that there are significant differences between the four groups. It appears from the production of $\mathrm{F}=$ 3.651 and significant at $\mathrm{p}<0.05$.

TABLE VI

RESULTS OF ANALYSIS OF VARIANCE FOR ACHIEVEMENT

\begin{tabular}{lccccc}
\hline Source & DB & $\begin{array}{c}\text { number } \\
\text { square }\end{array}$ & $\begin{array}{c}\text { Squares } \\
\text { Mean }\end{array}$ & $\begin{array}{c}\text { F } \\
\text { Ratio }\end{array}$ & F Prob \\
\hline Inter-group & 3 & 746.420 & 301.019 & 3.651 & 0.041 \\
In Group & 96 & 6731.204 & 98.010 & & \\
Total & 99 & 7320.8731 & & & \\
\hline
\end{tabular}

From the results of the analysis of variance followed by a Least Significant Test differences between groups to compare simultaneously (multicomparison). The results of the analysis as shown in Table 7. 
TABLE VII

TEST RESUlTS MULTIKOMPARASI THE LEAST SIGNIFICANT DIFFERENCES ATTRIBUTIONAL FEEDBACK ON STUDENT ACHIEVEMENT

\begin{tabular}{|c|c|c|c|c|c|}
\hline Mean & Group & (1) & (2) & (3) & (4) \\
\hline 36.105 & Oral Feedback & (1) & & & $*$ \\
\hline 26.437 & Feedback Writing & (2) & & $*$ & \\
\hline 35.557 & $\begin{array}{l}\text { feedback } \\
\text { Strengthening }\end{array}$ & (3) & & & $*$ \\
\hline 26.021 & Control & (4) & & & \\
\hline
\end{tabular}

Table 7 shows the significance of differences in the effectiveness of their consistency attributional feedback such as when performed on self-efficacy variables namely the groups (1) feedback attributional spoken with controls; (2) strengthening the attributional feedback control; and (3) writing with reinforcement feedback so that it can be understood also that the group of students who received verbal feedback and reinforcement attributional significantly higher academic achievement than those given no treatment (control).

Furthermore, the results of the factorial analysis that compared the efficacy of self-low achieving students (underachievers) with student-achievement-less (low achievers) as listed in Table 8.

TABLE VIII

ANALYSIS OF SELF-EFFICACY FACTORIZATION STUDENT-ACHIEVEMENT-LOW AND LEARNER AND ACHIEVEMENT-LESS

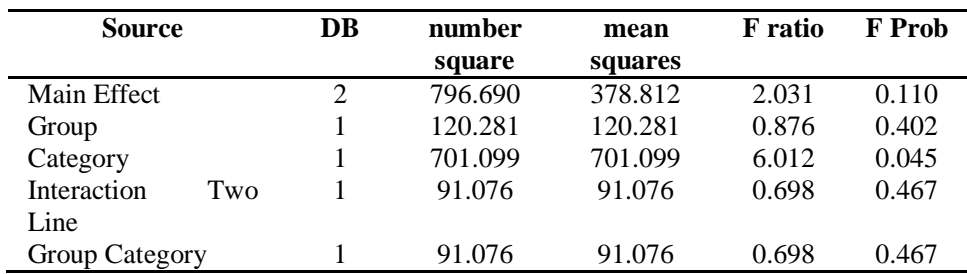

Table 8 above shows that the price of the F significant at $\mathrm{p}$ $<0.05$ is located on the main effect of the category of lowachieving students $(F=6.012$ significant at $0.045<0.05)$ While the main effect of the treatment group oral and written feedback was not significant $(\mathrm{F}=0.876)$, as well as their interaction effect was also not significant $(\mathrm{F}=0.698)$. Thus, the hypothesis that the low-achieving students after receiving treatment then their self-efficacy will be higher than the student-achievement-less evident in this study.

Finally, the results of the factorial analysis that compares student achievement-low-achievers (underachievers) with student-achievement-less (low achievers) as listed in Table 9.

Table 9 above shows that the price of the F significant at $p$ $<0.05$ was located on the main effect of the category of lowachieving students $(\mathrm{F}=7.010$ significant at $0.021<0.05)$ While the main effect of the treatment group oral and written feedback was not significant $(\mathrm{F}=0.103)$, as well as their interaction effect was also not significant $(\mathrm{F}=0.989)$. Thus, it turns out to low-achieving students after receiving the treatment will be higher academic achievement than studentachievement-less.
TABLE IX

RESULTS OF THE FACTORIAL ANALYSIS STUDENT ACHIEVEMENTOUTSTANDING-LOW AND STUDENT-ACHIEVEMENT-LESS

\begin{tabular}{lccccc}
\hline \multicolumn{1}{c}{ Source } & DB & $\begin{array}{c}\text { number } \\
\text { square }\end{array}$ & $\begin{array}{c}\text { MeanSqua } \\
\text { res }\end{array}$ & F ratio & F Prob \\
& 2 & 467.690 & 237.610 & 3.217 & 0.069 \\
Main Effect & 1 & 0.613 & 0.613 & 0.103 & 0.967 \\
Group & 1 & 412.220 & 412.220 & 7.010 & 0.021 \\
Category & & 69.098 & 69.098 & 0.989 & 0.386 \\
$\begin{array}{lcccc}\text { Interactions } \\
\text { Line }\end{array}$ & & & & & \\
Group Category & 1 & 69.098 & 69.098 & 0.989 & 0.386 \\
\hline
\end{tabular}

The findings of this study indicate that oral attributional feedback and reinforcement proved effective to improve students' academic self-efficacy and mathematics achievement, feedback while writing less effective. Evidence of this can be attributed to the concept of "perceptual mood" of Richardson and Margulis (1981) which is in each individual when faced with a phenomenon or communicate with other individuals. Richardson and Margulis suggest there are four types of "perceptual mood", namely: visual, auditive, feeling, and sensing. For those students who are the visual type, then he will be perceiving something through the senses of vision (reading). For students who auditive types are more likely to perceive something through hearing. For students feeling types tend to be easier to perceive something through touches feelings. Meanwhile, for students who are the type of sense tends to be easier to perceive things through bodily touches (gesture).

Because the study was conducted on elementary school students Grades III and IV are still relatively low grade, then psychologically, according to Richardson and Margulis (1982) they will tend to more easily respond to feedback attributional given by the teacher through the words he heard from teachers ( attributional verbal feedback), touches bodily or "sensing" and touches the feelings or "feeling" as a reinforcement for her (attributional feedback gains) rather than having to read the attributional feedback provided through writing. The reality on the ground, often if the student's classes got a letter from the teacher (whether it contains announcements, newsletters, appeals, and the like) they tend to give their parents to read it rather than read it yourself. Seen in this light, it becomes very plausible and relevant if it turns out the findings of this study indicate that writing is not effective attributional feedback. The findings of this study are relevant to and corroborated by the findings of earlier as was done by Manning (1988) when he was doing a behavior modification through cognitive interventions to students of class I to II; Hurley research findings and Dobson (1991) when doing research to develop personal types of children in grade I to IV in particular on the behavior of helping others.

The study also found that attributional feedback orally, in writing, as well as more effective reinforcement to increase academic self-efficacy and learning achievement in lowperforming students (underachievers) rather than studentachievement-less (low achievers). It also can be understood as low-achieving students (underachievers) was actually basically has good potential. However, due to various factors (eg: the management of learning that is not interesting, the 
subject matter is less variable, or how teachers teach boring, etc.) Cause they can not realize its potential it became apparent ability in the form of academic achievement. This phenomenon may be referred, for example, in a study Yaumil Agoes End (Herrera, 2000) which mentions that 30\% of high school students who have the ability and high intelligence but low achievement. Research Herrera, et al. in 1996 were made to the junior high school students in West Java, East Java, Lampung, and West Kalimantan also reveal $20 \%$ of junior high school students who have the ability and high intelligence but low achievement. As well as research Herrera, et al. in 1997 conducted on elementary school students also reveals $22 \%$ of elementary school students who have the ability and high intelligence but low performance (Herrera, 2000).

Thus, low-achieving students (underachievers) were, in fact, students of high levels. Therefore, if in this study after getting treatment using attributional feedback later academic self-efficacy and academic achievement increases are relevant to the findings of previous studies. As affirmed in the findings of earlier that students who have high ability will tend to have efficacy for self-academic high and in turn can lead to the achievement of the learning achievement of high (Sanna, 1992; Betz \& Hackett, 1993; Post-Kammer \& Smith, 1985; Ross et al., 1985; Bores-Rangel et al., 1990; Church et al., 1992; Multon \& Brown, 1993). As for the studentachievement-less (low achievers) proved ineffective attributional feedback for the student group were truly among the potential possessed by the achievements obtained by equally low.

\section{CONCLUSION}

Based on the results of research and discussion, can be drawn the conclusion that: (1) an effective attributional feedback to improve students' academic self-efficacy in mathematics is an oral attributional feedback and reinforcement; (2) the effectiveness of the same was true when made to improve mathematics achievement; (3) attributional feedback posts are not effective for improving self-efficacy of academic and student achievement in mathematics lesson; (4) when viewed from a group of students, the oral and strengthening attributional feedback it is more effective to group-low achieving students (underachievers) rather than student-achievement-less (low achievers).

On the basis of the conclusion, it can be proposed a number of suggestions, namely: (1) as an effort to overcome the low self-efficacy or lack of self-confidence of elementary students when faced with mathematics and to improve mathematics learning achievement of elementary students, teachers need to apply this oral and oral attributional feedback in the teachinglearning process because in addition to being proven effective, its application is also not difficult; (2) because this research is only applied in grade III and IV elementary school, although there is an opinion that for low class still have difficulty for intervention attributional, but there need to be further research by involving students of class I and II so that the low self- efficacy of students when faced with mathematics subject can be intervened and prevented as early as possible.

\section{REFERENCES}

Allan, W. (2008). "Children Attribution for Success and Failure: Effects of Age and Attentional Focus." Journal of Educational Psychology, 80, 78-81.

Asrori, M. (2008). Faktor-faktor Determinan bagi Proses dan Hasil Belajar Siswa SMU se-Kalimantan Barat. Pontianak: Laporan Penelitian: Kerjasama Jarlit Kalbar dengan Balitbang Dikbud.

Bandura, A. (2007). "Self-Efficacy: Towards A Unifying Theory of Behavioral Change." Psychological Review, 84, 191-215.

Bandura, A. (2006). "Recycling Misconceptions of Perceived Self-Efficacy." Cognitive Therapy and Research, 8, 235-255.

Berk, LE (2009). Child Development. Boston: Allyn and Bacon.

Betz, NE \& Hackett, G. (2003). "The Relationship of Mathematics SelfEfficacy Expectation to Selection of Science-Based College Majors.' Journal of Vocational Behavior, 23, 329-345.

Bores-Rangel, E. et al., (2000). "Self-Efficacy in Relation to Occupational Consideration and Academic Performance in High School Equivalency Students." Journal of Counseling Psychology, 37, 407-418.

Church, AT et al., (2002). "Self-Efficacy for Career and Occupational Consideration in Minority High School Equivalency Students." Journal of Counseling Psychology, 39, 498-508.

Cozby, PC (2005). Methods in Behavioral Research. Third Edition, Hayfield Publishing Company.

Dweck, CS (2006). "Motivational Processing Affecting Learning." American Psychologist, 41, 1040-1048.

Elliot, ES \& Dweck, CS (2008). "Goals: An Approach to Motivation and Achievement." Journal of Personality and Social Psychology, 54, 5-12.

Forsterling, F. (2006). "Attribution Conception in Clinical Psychology." American Psychologist, 41, 275-285.

Goldman, L. (2008). Research Methods for Counselors: Practical Approach in Field Settings. New York: John Wiley \& Sons.

Gredler, M. (2002). Learning and Instruction: Theory into Practice. New York: Macmillan.

Heppner, PP et al. (2002). Research Design in Counseling. Pacific Grove, California: Brooks/Co $\neg$ le Publishing Company.

Herry, W. (2000). "Sistem Percepatan Kelas (Akselerasi) bagi Siswa yang Memiliki Kemampuan dan Kecerdasan Luas Biasa.” Jurnal Pendidikan dan Kebudayaan, Tahun ke-6, No.026, 496-509.

Hurley, KV \& Dobson, TE (2001). What's My Type? Use the Enneagram. San Francisco: Harper.

Juvonnen, JA (2008). "Outcome and Attributional Disagreement Between Students and Their Teachers." Journal of Educational Psychology, 80, 330-336.

Kerlinger, FN \& Pedhazur, EJ (1993). Multiple Regression in Behavioral Research. New York: Holt Rinehart \& Winston.

Kirk, RE (2002). Experimental Design: Procedures for the Behavioral Sciences. 2nd Edition, Monterey, California: Brooks/Cole.

Manning, BH (2008). "Application of Behavioral Modification: First and Third Graders' Self-Management of Classroom Behaviors.” American Educational Research Journal, 25, 193-212.

Minium, EW (1998). Statistical Reasoning in Psychology and Education. New York: John Wiley \& Sons.

Multon, KD \& Brown, SD (2003). "Relation of Self-Efficacy Belief and Academic Outcome: A Meta-Analytic Investigation." Journal of Counseling Psychology, 37, 407-418.

Overwalle, FV (2009). "Structure of Freshmen's Causal Attributions for Exam Performance.” Journal of Educational Psychology, 81, 400-407.

Popham, WJ \& Sirotnik, KA, (2003). Educational Statistics: Use and Interpretation. 2nd Edition, New York: Harper \& Row.

Post-Kammer, P. \& Smith, PL (2005). "Sex Differences in Career SelfEfficacy, Consideration, and Interest of Eight and Ninth Graders." Journal of Counseling Psychology, 32, 551-559.

Richardson, J. \& Margulis, J. (2001). The Magic of Rapport: How You Can Gain Personal Power in Any Situation. San Francisco: Harbor.

Ryckman, RM et al., (2002). "Development and Validation of a Physical SelfEfficacy Scale.” Journal of Personality and Social Psychology, 62, 754-766. 
Sanna, LJ (2002). "Self-Efficacy Theory: Implication for Social Facilitation and Social Loafing." Journal of Personality and Social Psychology, 62, 774-786.

Schunk, DH (2002). "Effect of Effort Attributional Feedback on Children's Perceived Self-Efficacy and Achievement." Journal of Educational Psychology, 74, 548-556.

Schunk, DH; Hanson, AR; \& Cox, PD (2007). "Peer-Model Attributes and Children's Achievement Behaviors." Journal of Educational Psychology, 79, 54-61.

Tankersley, K. (2003). “Teaching Math Their Way.” Educational Leadership, $50,12-13$.

Tuckman, BW (2008). Conducting Educational Research. New York: Harncourt Brace Javanovich, Inc.

Weiner, B. (2000). "History of Motivational Research in Education." Journal of Educational Psychology, 82, 416-622.

Weiner, B. (2002) "Motivation.” Dalam Marvin C. Alkin (Ed.), Encyclopedia of Educational Research, 3, 860-865.

Weiner, B. (2003). "Some Methodological Pitfalls in Attributional Research." Journal of Educational Psychology, 75, 530-543.

Weiner, B. (2008). "Attribution Theory and Attribution Therapy." Some Theoretical Observation and Suggestions." British Journal of Clinical Psychology, 27, 93-104.

Wittrock, MC (2006). "Students' Thought Processes." Handbook of Research on Teaching, New York: Macmillan. 